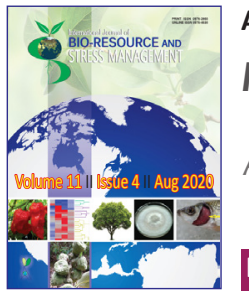

\title{
Construction of SSR Based Genetic Linkage Map and Identification of QTLs Conferring CMD Resistance in Cassava
}

\author{
P. Vidya ${ }^{*}$, Aswathy G. H. Nair, C. Mohan, J. Sreekumar and Ambu Vijayan
}

Division of Crop Improvement, ICAR-Central Tuber Crops Research Institute (ICAR-CTCRI), Sreekariyam, Thiruvananthapuram, Kerala (695 017), India

Corresponding Author
P. Vidya
e-mail: vidyapemail@gmail.com
Citation: Vidya et al., 2020. Construction of SSR
Based Genetic Linkage Map and Identification
of QTLs Conferring CMD Resistance in Cassava.
International Journal of Bio-resource and Stress
Management 2020, 11(4), 387-397. HTTPS://DOI.
ORG/10.23910/1.2020.2135.

Copyright: (c) 2020 Vidya et al. This is an open access article that permits unrestricted use, distribution and reproduction in any medium after the author(s) and source are credited.

Data Availability Statement: Legal restrictions are imposed on the public sharing of raw data. However, authors have full right to transfer or share the data in raw form upon request subject to either meeting the conditions of the original consents and the original research study. Further, access of data needs to meet whether the user complies with the ethical and legal obligations as data controllers to allow for secondary use of the data outside of the original study.

Conflict of interests: The authors have declared that no conflict of interest exists.

Acknowledgement: The authors are grateful to the Director, Head, Division of Crop Improvement, ICAR-CTCRI, Thiruvananthapuram, for providing the laboratory facilities to do the work and University Grant Commission (UGC) for providing the financial support

\begin{abstract}
Cassava mosaic disease (CMD) is one of the most devastating Gemini viral diseases that challenge the cassava production with great economic loss. Utilizing host plant resistance through marker assisted breeding is the best sustainable way to tackle this geminiviral disease. High disease severity and increasing yield loss demands the identification of new quantitative trait loci (QTLS) for CMD resistance. In the present study, an attempt was made to construct SSR based linkage map using bi-parental mapping population developed from a cross of cassava cultivars viz., MNga-1 and $\mathrm{Cl}-732$ and identified new QTLs using interval mapping. Thirteen CMD associated marker alleles were revealed through single marker analysis (SMA) and two new QTL regions were identified in linkage groups viz., chrom7 and chrom 22 using composite interval mapping (CIM). An epistatic interaction viz., additive-dominant (AD) and dominant-additive (DA) between QTLs in 0.1cM and $60.4 \mathrm{cM}$ of chrom7 was identified using multiple interval mapping (MIM). The heritability of resistance viz., broad sense heritability $\left(\mathrm{H}^{2}\right)$ and narrow sense heritability $\left(\mathrm{h}^{2}\right)$ were found to be $93 \%$ and $15 \%$ respectively. The expected gain from breeding population was found to be 0.4 .
\end{abstract}

Keywords: Cassava mosaic disease, linkage, QTL, SSR, interval mapping

\section{Introduction}

Cassava (Manihot esculenta) belonging to the family Euphorbiaceae, is one of the most important tuber crops cultivated extensively in tropical and subtropical regions of Africa and Asia. It is a cross pollinating crop with a diploid number of chromosome $2 \mathrm{n}=36$ and DNA content of $1.67 \mathrm{pg}$ per cell. It is highly heterozygous, monoecious and protogynous in nature. The tuberous crop is propagated vegetatively by means of stem cuttings and sexually through seeds. According to Food and Agriculture Organization Corporate Statistical Database (FAOSTAT, 2017), the global cassava production was estimated to be 291992646 tonnes in which $61 \%$ is accounted by Africa, $29.3 \%$ contributed by Asia and remaining $9.6 \%$ by America. Indian cassava production was accounted to be $42 \mathrm{mt}$ from an area of 199 mha with a productivity of 2,09,598 $\mathrm{hg} \mathrm{ha}^{-1}$.

Cassava is mainly used as food and also as an important raw material for various industrial purposes. The wide acceptability of cassava in the world is increasing due to the broad agro-ecological adaptability, its ability to mitigate unfavourable environmental condition and its abilities to produce reasonable yield. Cassava production is always challenged
Article History

RECEIVED in $16^{\text {th }}$ July 2020 RECEIVED in revised form $22^{\text {nd }}$ August 2020 ACCEPTED in final form $29^{\text {th }}$ August 2020 
by various biotic and abiotic stresses. One of the major constraints that affected the cassava production drastically is cassava mosaic disease (CMD), caused by geminivirus which are characterized by small, geminate particles containing circular, single-stranded DNA molecules (Briddon and Markham, 1995) encapsidated in paired icosahedral particles (Fauquet et al., 2008). CMD is prevalent in many parts of African and Indian sub-continent that causes serious yield losses (Sseruwagi et al., 2004). In Africa, the estimated yield losses ranging from 25 to 95\% (Fauquet and Fargette, 1990), whereas in India 20 to $80 \%$ of yield losses were reported (Nair and Unnikrishnan, 2007).

CMD was first reported in India by Abraham (1956), but a detailed study was carried out by Alagianagalingam and Ramakrishnan (1966). The important geminivirus causing CMD were isolated from different countries includes African Cassava Mosaic Virus (ACMV), East African Cassava Mosaic Virus (EACMV), East African Cassava Mosaic VirusUgandan strain (EACMV-UG), South African Cassava Mosaic Virus (SACMV), East African Cassava Mosaic Cameroon Virus (EACMCV), East Africa Cassava Mosaic Malawi Virus (EACMMV) and East African Cassava Mosaic Zanzibar Virus (EACMZV), East African Cassava Mosaic Kenya Virus (EACMKV), African Cassava Mosaic Burkina Faso Virus (ACMBFV) and Cassava Mosaic Madagascar Virus (CMMGV), Indian Cassava Mosaic Virus (ICMV) and Sri Lankan Cassava Mosaic Virus (SLCMV). Two cassava mosaic geminivirus (CMGs) reported from Indian sub-continents were ICMV and Sri Lankan cassava mosaic virus (SLCMV) (Saunders et al., 2002). CMD is characterized by chlorotic mosaic of leaves, premature leaf abscission, leaf distortion and severe stunting of plant ultimately affected the photosynthesis of the plant and thereby yield. Variation in symptom expression might be due to sensitivity of host genotype, season, stage of crop growth, difference in virus strain (Fargette et al., 1990). Whitefly, Bemisia tabacia is the vector and is transmitted in a circulative, non-propagative mechanism (Harrison, 1985). The direct effect of CMD epidemic spread is serious crop failure thereby yield losses and the severity of losses depends upon the viral strains, crop varieties, age of the crop and varying environmental conditions.

Development and deployment of resistant cultivars through breeding was the most effective control method for CMD (Thottappilly et al., 2004). CMD resistance breeding studies using inter-specific and intra-specific crosses were initiated in the early 1940s led to the development of highly CMD resistance breeding materials such as TMS (Hahn et al., 1980) and TME series (Okogbenin et al., 2012) in Africa. MAS is a method whereby a phenotype was selected based on the genotype of a marker (Collard et al., 2005). Identifying resistance genes using molecular markers was the basic pre-requisite for performing MAS in resistance breeding programs (Pinheiro et al., 2012). The two main strategies used to identify molecular markers associated with traits of interest were QTL mapping and bulk segregant analysis (BSA)
(Tanksley et al., 1989; Michelmore et al., 1991; Giovannoni et al., 1991). Genome mapping or genetic mapping is the process of constructing linkage maps and conducting QTL analysis to identify genomic regions associated with a particular trait (McCouch and Doerge, 1995; Mohan et al., 1997; Paterson, 1996). Till now, three major sources of resistance were reported in cassava against CMD. The first source of resistance identified was designated as CMD1 and was introgressed from wild cassava Manihot glaziovii. The marker associated with source of resistance was SSRY40 and cassava lines developed was termed as Tropical Manihot Selection (TMS). The CMD1 resistance was considered as polygenic and recessive (Fregene et al., 1997). The second source of resistance was monogenic dominant gene (Qualitative resistance), reminiscent of plant resistance genes (R-genes) whose product played a key role in recognizing a hypersensitive response (HR), a localized cell death and tissue necrosis at the site of pathogen ingress and was designated as CMD2 (Akano et al., 2002). This source of resistance was identified in Nigerian landraces were later termed Tropical Manihot Esculenta (TME). The nearest markers associated with CMD2 identified were SSRY28, NS158, NS169 and RME-1. The third source of resistance was quantitative trait loci (QTL) designated as CMD3 and the marker NS198 were found to be associated with this resistance (Okogbenin et al., 2012).

Resistant cultivars are much less readily infected than the susceptible cultivars with the localized distribution and low concentration of virus in resistant cultivars made them a less potent source of inoculum from which spread could occur (Fargette et al., 1988). But with the emergence of new viral strains, its high virulence and increasing adaptability with vector became a huge challenge to conventional breeding programs. Classical breeding in cassava was also complicated due to strong heterozygosity, inbreeding depression coupled with lengthy breeding cycles and the need for making large number of crossings to obtain the first generations progenies, which were then screened for desired traits (Ceballos et al., 2004). Moreover, most of the agronomically important traits studied in cassava were polygenic (Hahn et al., 1989) and were very difficult to analyze using classical genetic analysis. Identifying and pyramiding different virus resistance genes will therefore provide stable resistance against a broad spectrum of CMGs. Gene pyramiding in cassava require molecular marker assisted selection (MAS) to expedite the breeding process. Important molecular markers particularly promising in assisting the selection for desirable characters are Restriction Fragment Length Polymorphisms (RFLP), Random Amplified Polymorphic DNA (RAPD), Sequence Characterized Amplified Regions (SCAR), Sequence-Tagged Sites (STS), Inter Simple Sequence Repeat (ISSR), Amplified Fragment Length Polymorphic DNA (AFLP), Simple Sequence Repeat (SSR), Single Nucleotide Polymorphism (SNP), Diversity Arrays Technology (DArT).

Genome mapping or genetic mapping is the process of constructing linkage maps and conducting QTL analysis to 
identify genomic regions associated with a particular trait (Mohan et al., 1997). Linkage map construction requires a segregating mapping population derived from parents that differ for one or more traits of interest. In cross pollinating crop, the $F_{1}$ mapping populations were successfully developed by pairing two heterozygous parents that were distinct in trait of interest (Barrett et al., 2004). Cassava being out crossing crop, the heterozygous nature of mating types made the QTL detection more complex and less efficient compared to inbreds (Sliwka et al., 2008). The entire mapping population were partitioned in to different genotypic groups based on the presence or absence of a particular marker locus and to determine whether significant difference exist between groups with respect to the trait being measured (Tanksley, 1993; Young,1996). Loci associated with quantitative traits have commonly been referred to as QTL and the procedures used to find out QTLs are called QTL mapping. Cassava is a highly heterozygous and cross pollinating crop; thus $F_{1}$ mapping population was generally used for genetic linkage map construction. Allelic determination and its segregation in mapping population could be analyzed using a special class of markers known as single dose restriction fragments (SDRF) (Wu et al., 1992). SDRFs are DNA markers that are present in one parent and absent in the other and segregate in a 1:1 ratio (absence:presence) in the progeny. Another important factor in linkage map construction is the selection of molecular markers in mapping studies. Microsatellites or SSR markers are highly reproducible and show co-dominant inheritance makes it a simple, cheap and reliable marker for MAS. The high polymorphism of SSR markers were due to its high mutation rate and random occurrence in the genome that makes SSR the most promising class of markers for construction of saturated maps.

The two major type of plant defense mechanism were quantitative and qualitative mode of resistance (Toojinda et al., 2000), of which qualitative resistance was mediated by major genes and quantitative resistance by multiple genes (Kousik and Ritchie, 1999). CMD is a viral disease showing varying symptom expression from resistance to very severe symptom. The varying disease symptom expressions of the plant were explained by both quantitative and qualitative mode of resistance. The quantitative resistance in cassava was derived from M. glaziovii through inter-specific crosses and was found to be recessive with a heritability of about $60 \%$ (Nichols, 1947; Jennings, 1976). The second source of resistance identified was qualitative conditioned by single dominant gene in landraces from Nigeria and other West African countries (Akano et al., 2002). But the limited genetic base for the dominant resistance implies potential vulnerability if the cassava mosaic geminivirus could evolve to overcome it. Qualitative resistance was thought to be R-mediated resistance which provides high level of resistance and is segregated in 3:1 ratio. On the other hand, quantitative resistance $(Q R)$ is a highly durable broad-spectrum resistance mediated by multiple genes with minor effects. These kinds of resistance are very effective against biotrophs such as virus and it resulted in the continuous distribution of disease severity score. Though different sources of resistance had been identified, the exact gene responsible for $\mathrm{CMD}$ resistance is still unknown. Several studies were carried out to dissect the genetic basis of qualitative resistance. Recently Wolfe et al. (2016) conducted genome wide association mapping (GWAM) to study the CMD2 locus and identified candidate genes viz., two peroxidase and one thioredoxin gene for $\mathrm{CMD}$ resistance. A clear understanding of the CMD resistance mechanism particularly at genomic level will be useful in breeding process and also helpful in the proper selection of plants by MAS. The objective of the current study was to develop a full-sib mapping population for $\mathrm{CMD}$ resistance and the identification of QTL markers conferring resistance to CMD.

\section{Materials and methods}

\subsection{Selection of parental lines}

In this study, two cassava genotypes were selected viz., $\mathrm{Cl}-732$ and MNga-1 as female and male parent to develop full-sib mapping population which were indexed as score 5 and score 1 respectively. $\mathrm{Cl}-732$ is a CMD susceptible local genotype and MNga-1 (TMS30001) is CMD resistant genotype developed by the International Institute for Tropical Agriculture (IITA), Nigeria. This Study was conducted at ICAR-Central Tuber Crops Research Institute (ICAR-CTCRI) from 2011 to 2015. In this study, both MNga- 1 and $\mathrm{Cl}-732$ were planted in four rows with 25 mounts in each row. The parental lines were crossed and produced $114 \mathrm{~F}_{1}$ mapping population. The phenotypic evaluations of the $F_{1}$ mapping population for CMD resistance were done based of 1-5 symptom severity index (SSI) (Hahn et al., 1980; Table 1). In order to avoid bias, clones of each genotype were prepared using five cuttings from each genotype and were planted in a row. Two clonal evaluation trials for CMD response were carried out and the response

Table 1: CMD symptom severity score to determine the level of resistance

\begin{tabular}{lc}
\hline Symptom severity & Score \\
\hline Unaffected plant, no disease symptom & 1 \\
Mild chlorosis, mild distortions at the base of most & 2 \\
leaves, while the remaining part of the leaves and & \\
leaflet appear green and healthy & \\
Pronounced mosaic pattern on most leaves, & 3 \\
narrowing and distortion of the one-third of the & \\
leaflets & \\
Severe mosaic distortions of two thirds of most & 4 \\
leaves and general reduction of leaf size and stunting & \\
of shoots & \\
Very severe mosaic symptoms on all leaves, & 5 \\
distortions, twisting, misshapen and severe leaf & \\
reductions of most leaves accompanied by severe & \\
stunting of plants. & \\
\hline
\end{tabular}


of each $F_{1}$ seedlings to CMD were recorded at 3 month after planting ( 3 MAP), 5 MAP and 8 MAP after planting based on 1-5 SSI. Maximum symptom expression was found to be at 5MAP. All managemental practices were followed as per the recommended package of practices.

\subsection{Detection of geminivirus in parental lines using ICMV and SLCMV specific primer}

The geminivirus present in the parental lines viz., MNga-1 and $\mathrm{Cl}-732$ were detected using ICMV and SLCMV specific primers (Table 2). The total DNA was extracted from two parental lines using the same procedure as employed in chapter 3. Standard PCR was carried out by using specific primers designed from replicase gene sequence of both the viruses (Raghu et al., 2012). A $20 \mu \mathrm{l}$ PCR reaction was carried out in Bio-Rad C1000 ${ }^{\mathrm{TM}}$ Thermal Cycler containing 50ng genomic DNA, $0.2 \mu \mathrm{M}$ each of forward and reverse primers, $50 \mu \mathrm{M}$ dNTPs, $1 \mathrm{X}$ buffer (10mM Tris- $\mathrm{HCl}(\mathrm{pH} 8.3) 50 \mathrm{mM} \mathrm{KCl}, 1.5 \mathrm{mM} \mathrm{MgCl}_{2}, 0.3 \mathrm{U}$ of Taq DNA polymerase. PCR parameters were 94 으 $\mathrm{C}$ for $2 \mathrm{~min}$ then 40 cycles of $1 \mathrm{~min}$ at $94^{\circ} \mathrm{C}, 1 \mathrm{~min}$ at $63^{\circ} \mathrm{C}$ and $1 \mathrm{~min}$ at $72{ }^{\circ} \mathrm{C}$, followed by the final extension of $10 \mathrm{~min}$ at $72{ }^{\circ} \mathrm{C}$. The amplified PCR products were checked on $1.5 \%$ agarose gel stained with $10 \mathrm{mg} \mathrm{ml}^{-1}$ of ethidium bromide and images were photographed in gel documentation system (Alpha Imager).

\begin{tabular}{|c|c|c|}
\hline Primers & Sequence $\left(5^{\prime}-3^{\prime}\right)$ & $\begin{array}{c}\text { Base } \\
\text { Pair (bp) }\end{array}$ \\
\hline $\begin{array}{l}\text { ICMV } \\
\text { replicase } \\
\text { primer }\end{array}$ & $\begin{array}{l}\text { F: 5'-TGTGACCTTGATTGGCACCTG-3' } \\
\text { R: 5'-CTCGACGAGTGGTTTCACGA-3' }\end{array}$ & 428 \\
\hline $\begin{array}{l}\text { SLCMV } \\
\text { replicase } \\
\text { primer }\end{array}$ & $\begin{array}{l}\text { F: 5'-TAGCTGCCCTGTGTTGGAC-3' } \\
\text { R: 5'-TGAGAAACCCACGA TTCAGA-3' }\end{array}$ & 1050 \\
\hline
\end{tabular}

\subsection{Construction of genetic linkage map and QTL mapping}

The genomic DNA was isolated from both parents and $F_{1}$ progenies using Cetyl trimethyl ammonium bromide (CTAB) method (Doyle and Doyle, 1990). The quality and purity of the DNAs were checked using $0.8 \%$ agarose gel and stained with ethidium bromide solution. The DNA bands were visualized using UV illumination system and gel images were taken using Gel documentation system (Alpha Imager). The quantification of DNA was determined on the basis of optical density readings (ODs) read at wavelengths of $260 \mathrm{~nm}$ and 280 $\mathrm{nm}$. The concentration of DNA samples were then adjusted to $50 \mathrm{ng} / \mu \mathrm{l}$ (vidya et al., 2019). A total of 117 SSR primer pairs were used to detect the parental polymorphism. PCR conditions were maintained as described by Mba et al. (2001). A $20 \mu \mathrm{l}$ PCR reaction was carried out in Bio-Rad C1000 ${ }^{\mathrm{TM}}$ Thermal Cycler containing 50 ng genomic DNA, $0.2 \mu \mathrm{M}$ each of forward and reverse primers, $50 \mu \mathrm{M}$ dNTPs, $1 \mathrm{X}$ buffer (10 $\mathrm{mM}$ Tris- $\mathrm{HCl}(\mathrm{pH} 8.3), 50 \mathrm{mM} \mathrm{KCl}, 1.5 \mathrm{mM} \mathrm{MgCl}_{2}$ ), $0.3 \mathrm{U}$ of Taq polymerase. A PCR profile of $94{ }^{\circ} \mathrm{C}$ for $5 \mathrm{~min}$ then 30 cycles of $1 \mathrm{~min}$ at $94^{\circ} \mathrm{C}, 2 \mathrm{~min}$ at $58^{\circ} \mathrm{C}$ and $2 \mathrm{~min}$ at $72{ }^{\circ} \mathrm{C}$, followed by the final extension of $5 \mathrm{~min}$ at $72{ }^{\circ} \mathrm{C}$. A volume of $8 \mu \mathrm{l}$ of loading dye was added to each of the amplified product which was then denatured at $95{ }^{\circ} \mathrm{C}$ for $5 \mathrm{~min}$, snap cooled using ice and separated on $6 \%$ denaturing polyacrylamide gel electrophoresis (PAGE) containing $7 \mathrm{M}$ urea at a constant current of $100 \mathrm{~W}$. Then the amplified products were resolved using silver stain as described by Panaud et al. (1996). The identified polymorphic markers were used in the genotyping of parental lines along with $F_{1}$ mapping population. The true hybrid analysis of $F_{1}$ mapping population was carried out using size specific polymorphic markers especially markers produced single alleles in parental lines. Seven single allelic size specific polymorphic markers (SSRY95, SSRY33, SSRY83, SSRY339, SSRY47, MeSSR10 and NS890) obtained from parental analysis were used in true hybrid evaluation (Vidya et al., 2019).

The genotypic scoring was performed as SDRF as described by Wu et al. (1992). The entire genotypic data was used to construct linkage map using a computer software program MAPMAKER v3.0 (Lincoln et al., 1993) and markers were sorted into different linkage groups based on a LOD threshold of 3.0 with a maximum recombination fraction of $50 \mathrm{cM}$. The marker alleles were tested for goodness-of-fit for Mendelian segregation using Chi-square $\left(\chi^{2}\right)$ analysis. QTL mapping were carried out by three different methods viz., single marker analysis (SMA), Composite interval mapping (CIM) and multiple interval mapping (MIM) using Windows QTL Cartographer version 2.5 (Basten et al., 2003). Single marker analysis (SMA) was performed by both one way ANOVA in Microsoft EXCEL and simple linear regression analysis in Windows QTL Cartographer version 2.5. In composite interval mapping, LOD value was determined by the genome-wide significant threshold level which itself was calculated by permutation test carried out at 1000 replicates. CIM was performed at $5 \%$ level of significant using the parameters viz., forward and backward regression, Model-6 standard model, 10 control markers and a walk speed of 1cM (Jansen, 1993; Jansen and Stann, 1994; Zeng, 1993, 1994). Multiple interval mapping was using performed using the parameters viz., MIM forward scan at 5\% significant levels and at a walk speed of 1cM to find out the main QTLs, its exact positions and interaction of QTLs for a particular trait (Kao et al., 1999).

\subsection{Heritability and expected genetic advance}

The Broad-sense heritability $\left(\mathrm{H}^{2}\right)$ and narrow sense heritability $\left(\mathrm{h}^{2}\right)$ of the trait were calculated using the formula

$H^{2}=\left(V_{G} \div V_{p}\right) \times 100 \quad h^{2}=\left(V_{A} \div V_{p}\right) \times 100$

$\left(V_{G}\right.$ is the total genetic variance (additive, dominant and epistatic), $\mathrm{V}_{\mathrm{A}}$ is the total additive variance)

The expected advance or gain from the current breeding population were calculated using the formula $G_{c}=(k)\left(V V_{p}\right) h^{2}$ $\left(G_{c}=\right.$ genetic advance or gain, $V_{\mathrm{p}}=$ square root of phenotypic variance, $k=$ Selection intensity (1.76)). 


\section{Results and Discussion}

\subsection{Detection of geminivirus in parental lines using ICMV and SLCMV specific primer}

CMD is one of the most devasting diseases that cause a serious yield losses in major cassava growing countries of tropics and sub-tropical regions. In Africa, CMD related yield losses was estimated to be 20 to 95\% (Fauquet and Fargette, 1990) and a severe losses of more than 19 million tons of cassava valued above US\$1.9 billion was reported in 2003 (Legg and Fauquet, 2004). In India, yield losses of 16 to $80 \%$ was reported (Nair and Unnikrishnan, 2007). The causative agent of CMD was geminivirus that was transmitted either through the use of infected stem cuttings or by whitefly vector B. tabaci. The major geminivirus prevalent in Africa is ACMV and in India, two geminivirus has been reported viz., ICMV and SLCMV. In the present study, an attempt was undertaken to identify the causative agent of CMD using specific primer pairs designed from ICMV and SLCMV replicase gene in parental lines viz., MNga-1 (resistant to CMD and $\mathrm{Cl}-732$ (susceptible to CMD) collected from the fields of ICAR-CTCRI. In this study, amplification in specific band size of 1050bp confirmed the presence of SLCMV and no amplification was recorded for ICMV in both samples indicated the absence of ICMV. It was also found that a very thick band was observed in susceptible variety $(\mathrm{Cl}-732)$ and a very light band in resistant variety gave qualitative account on the amount of virus in the susceptible and resistant samples (MNga-1; Figure 1). But previous

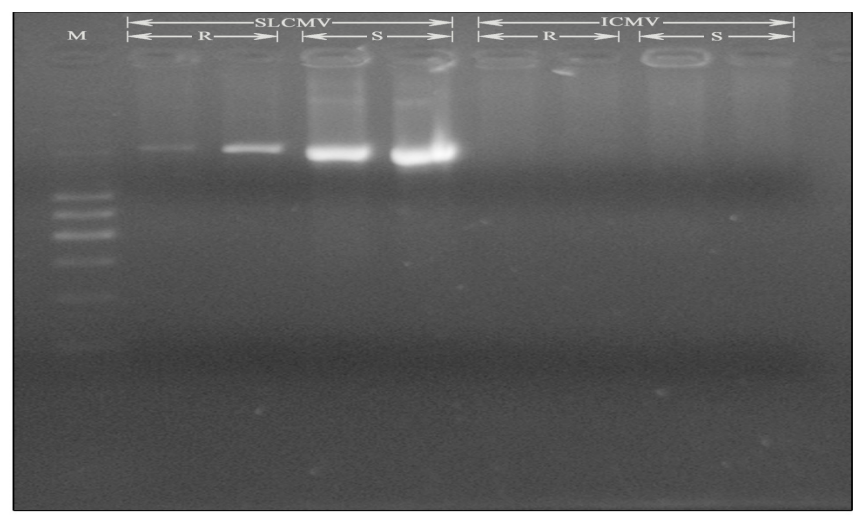

Figure 1: Amplification with SLCMV and ICMV specific primers

study conducted by Mohan et al. (2013a) using the parental lines viz., MNga-1 and $\mathrm{CO}_{2}$ detected the presence of ICMV but not SLCMV. Studies of Raghu et al. (2012) reported the presence of both ICMV and SLCMV in cassava variety H-226 using specific primers pairs designed from ICMV and SLCMV replicase gene. But the above mentioned two studies were carried out using the infected leaf samples collected from fields of TNAU campus, Coimbatore. The virulence of SLCMV and ICMV to cause disease in host plant was revealed through the work of Saunders et al. (2002) and found that SLCMV was more virulent in host than ICMV. It was also found that the DNA B of SLCMV was originated from DNA B of ICMV by recombination event involving DNA A of SLCMV.

\subsection{Construction of genetic linkage map and QTL mapping}

Cassava is an important starchy tuberous root crop cultivated for more than a decade which provides food for all the tropical countries of the world. It is highly heterozygous and cross pollinating crop with long breeding cycle render the conventional breeding tedious. Hence to understand many agronomically important traits in cassava, MAS using DNA markers has become an important choice. DNA markers tightly associated with a particular trait whose presence or absence is used in MAS to assist phenotypic selection. The prime most steps in MAS are the construction of linkage map followed by the identification of QTLs for a particular trait. Linkage map is the road map which shows the position and relative distance between the markers along the chromosome. Three important steps involved in linkage map construction were development of mapping population, identification of polymorphism and finally linkage analysis of markers (Collard et al., 2005). A segregating mapping population with 50 to 250 individuals from two genetically divergent parents for one or two traits is generally employed in linkage map construction (Mohan et al., 1997). Due to the high inbreeding depression in cassava, $F_{1}$ mapping population derived from highly heterozygous parents are generally used in linkage mapping. The present study made an attempt to develop $114 \mathrm{~F}_{1}$ mapping population from MNga-1 (male parent) and $\mathrm{Cl}-732$ (female parent) which were contrasted in CMD resistance. The parental analysis with 117 SSR primer pairs identified 65.8 per cent polymorphism (Figure 2). The polymorphic SSR primer pairs were used in the genotyping of $F_{1}$ mapping population and their segregation among mapping population were scored using SDRF producing 113 segregating loci.

A genetic linkage map comprising 24 linkage groups spanned a genetic distance of $1165.9 \mathrm{cM}$ was constructed with 70 polymorphic SSR markers (Table 3, Figure 3). The number of linkage group exceeds above the expected number of linkage group in cassava (18 linkage group) explained the incomplete coverage of genome with SSR markers and similar situation was observed in studies of Okogbenin et al. (2006), Sraphet et al. (2011). One of major problem encountered in mapping studies were segregation distortion. Cassava being an outbreeding crop showed a very high segregation distortion and was reported to be common in all out crossing crops (Hanley et al., 2002; Liebhard et al., 2002).

The usual way to assess segregation distortion for marker data is by $\chi^{2}$ tests (Haitham et al., 2002; Lu et al., 2002; Ruiz and Asins, 2003). In the current study, Ninety three (82.3\%) primers showed 1:1 disomic segregation pattern and twenty marker alleles (17.69\%) showed deviations from Mendelian segregation pattern. The reason for segregation distortion might be due to the presence of gametophytic selection for sub-lethal genes (Yan et al., 2005) or due to the high 


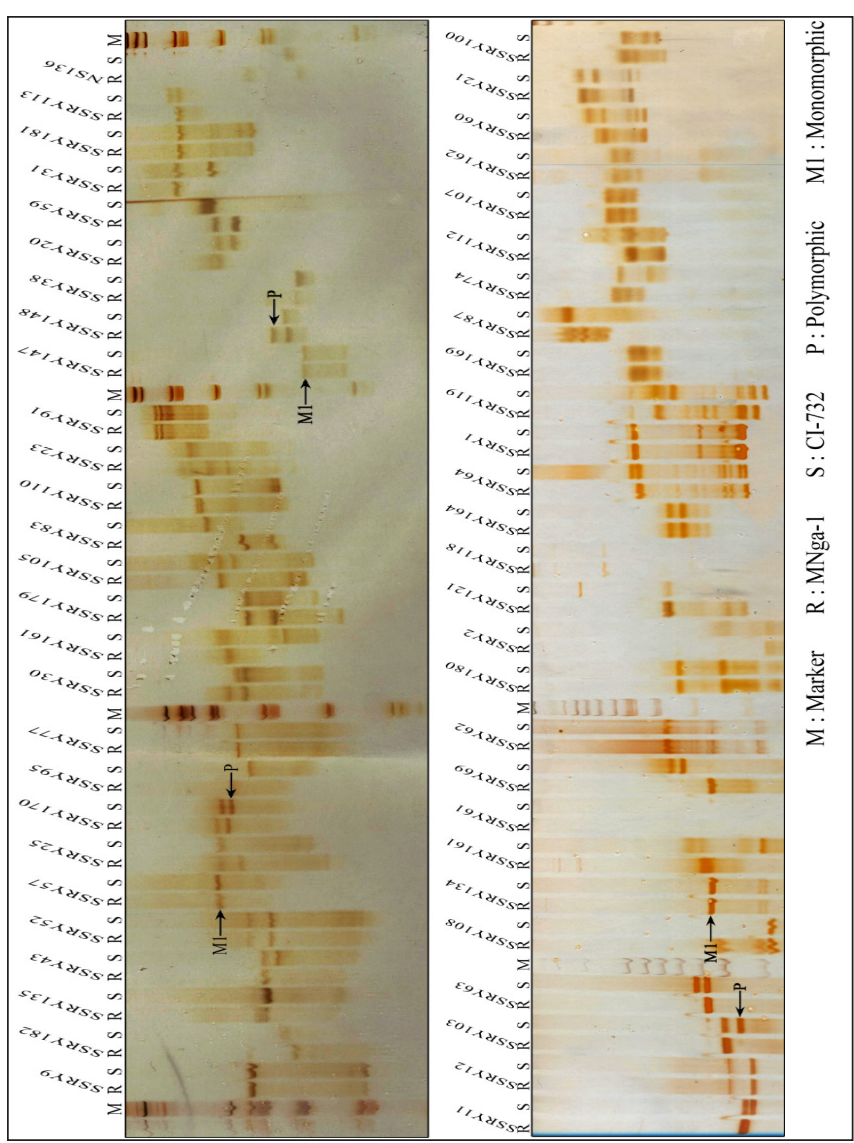

Figure 2: Detection of parental polymorphism using SSR primers

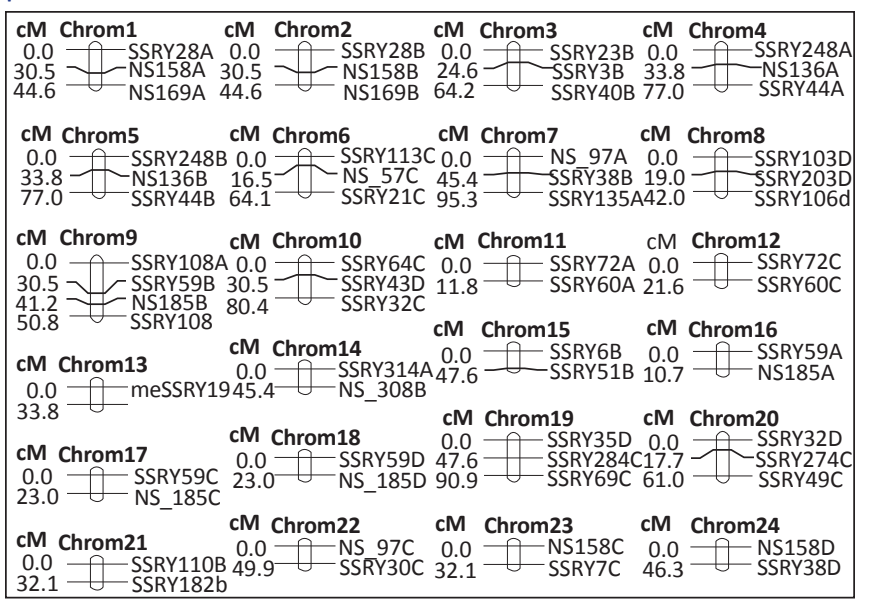

Figure 3: SSR based genetic linkage map developed from $F_{1}$ mapping population of MNga-1 and $\mathrm{Cl}-732$

recombination event (Nordborg, 2000).

CMD is a geminiviral showing varying symptom expressions. When disease resistance is inherited in a complex manner, progenies will exhibit quantitative mode of resistance showing low to high disease severity resembling a normal distribution (Miedaner and Korzun, 2012) and thus the identification of QTLs holding resistance is a necessity to achieve durability resistance against CMD. In the present study, two clonal

\begin{tabular}{|c|c|c|c|}
\hline $\begin{array}{l}\text { Linkage } \\
\text { group }\end{array}$ & $\begin{array}{l}\text { Size } \\
(\mathrm{cM})\end{array}$ & $\begin{array}{c}\text { No. of } \\
\text { markers }\end{array}$ & $\begin{array}{c}\text { Average marker } \\
\text { interval (cM) }\end{array}$ \\
\hline chrom1 & 44.5 & 3 & 22.3 \\
\hline chrom2 & 44.5 & 3 & 22.3 \\
\hline chrom3 & 64.2 & 3 & 32.1 \\
\hline chrom4 & 77.0 & 3 & 38.5 \\
\hline chrom5 & 77.0 & 3 & 38.5 \\
\hline chrom6 & 64.1 & 3 & 32.05 \\
\hline chrom7 & 95.3 & 3 & 47.65 \\
\hline chrom8 & 42.0 & 3 & 21 \\
\hline chrom9 & 50.8 & 4 & 16.9 \\
\hline chrom10 & 80.4 & 3 & 40.2 \\
\hline chrom11 & 11.8 & 2 & 11.8 \\
\hline chrom12 & 21.6 & 2 & 21.6 \\
\hline chrom13 & 33.8 & 2 & 33.8 \\
\hline chrom14 & 45.4 & 2 & 45.4 \\
\hline chrom15 & 47.6 & 2 & 47.6 \\
\hline chrom16 & 10.7 & 2 & 10.7 \\
\hline chrom17 & 23.0 & 2 & 23.0 \\
\hline chrom18 & 23.0 & 2 & 23.0 \\
\hline chrom19 & 90.9 & 3 & 45.45 \\
\hline chrom 20 & 61.0 & 3 & 30.5 \\
\hline chrom 21 & 32.1 & 2 & 32 \\
\hline chrom 22 & 49.9 & 2 & 49.9 \\
\hline chrom 23 & 32.1 & 2 & 32.1 \\
\hline chrom 24 & 43.2 & 2 & 43.2 \\
\hline$\Sigma /$ mean & $1165 . .9$ & 61 & 31.73 \\
\hline
\end{tabular}

phenotypic evaluation trials for CMD resistance were carried out in two consecutive years (2013-14, 2014-15). Disease severity expression was recorded at $3 \mathrm{MAP}, 5 \mathrm{MAP}$ and $8 \mathrm{MAP}$ and the maximum disease severity was observed in $5 \mathrm{MAP}$ which was recorded as the final CMD score. Fourty five $F_{1}$ progenies showed symptom severity score of 1 followed by 22 individuals with a score 4, 20 individuals with score 3, 17 individuals with score 2 and 10 individuals showed a very severe symptom score of 5 . The mean symptom severity value was found to be 2.42 with a variance of 1.96 (Figure 4).

When disease resistance is inherited in a complex manner, progenies will exhibit quantitative mode of resistance showing low to high disease severity resembling a normal distribution (Miedaner and Korzun, 2012) and thus the identification of QTLs holding resistance is a necessity to achieve durability resistance against CMD. In the present study, four different methods have been employed in QTL mapping studies viz., 


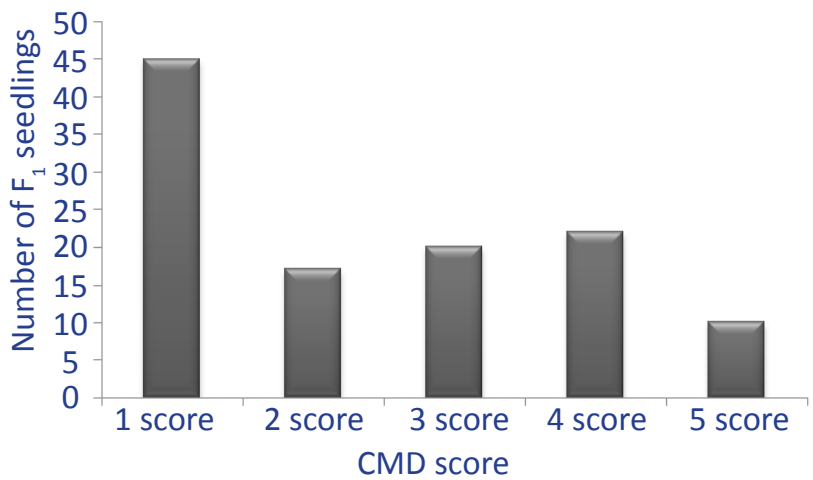

Figure 4: Distribution of $F_{1}$ progenies (clonal stage) based on symptom severity score

SMA, SIM, CIM and MIM. Thirteen marker alleles (SSRY28a, SSRY28b, SSRY324d, SSRY59a, SSRY59b, SSRY43d, SSRY32c, SSRY32d, SSRY10b, SSRY30c, NS97c, NS185a and NS185b) revealed through SMA have been found to be significantly associated with CMD resistance $(p<0.01)$, consisting twelve linked markers and one unlinked marker (SSRY324d) (Table 4). The distribution of currently identified CMD associated markers in different linkage groups and the contribution from female parent reconfirmed the polygenic means of resistance

Table 4: SSR markers associated with CMD resistance identified by SMA

\begin{tabular}{|c|c|c|c|c|c|}
\hline $\begin{array}{l}\text { SL. } \\
\text { No. }\end{array}$ & $\begin{array}{l}\text { Linkage } \\
\text { group }\end{array}$ & Markers & F-value & P-value & F-critical \\
\hline 1. & chrom1 & SSRY28a & 5.51 & $0.020^{*}$ & 3.92 \\
\hline 2. & chrom2 & SSRY28b & 5.51 & $0.020^{*}$ & 3.92 \\
\hline 3. & Unlinked & SSRY324d & 4.45 & $0.035^{*}$ & 3.92 \\
\hline 4. & chrom16 & SSRY59a & 4.51 & $0.015^{*}$ & 3.92 \\
\hline 5. & chrom9 & SSRY59b & 4.51 & $0.015^{*}$ & 3.92 \\
\hline 6. & chrom10 & SSRY43d & 9.19 & $0.003^{* *}$ & 3.92 \\
\hline 7. & chrom10 & SSRY32c & 5.79 & $0.017^{*}$ & 3.92 \\
\hline 8. & chrom19 & SSRY32d & 5.79 & $0.017^{*}$ & 3.92 \\
\hline 9. & chrom9 & SSRY10b & 6.09 & $0.004^{* *}$ & 3.92 \\
\hline 10. & chrom21 & SSRY30c & 8.60 & $0.004^{* *}$ & 3.92 \\
\hline 11. & chrom9 & NS185a & 6.21 & $0.014^{*}$ & 3.92 \\
\hline 12. & chrom16 & NS185b & 6.21 & $0.014^{*}$ & 3.92 \\
\hline 13. & chrom21 & NS97c & 8.60 & $0.004^{* *}$ & 3.92 \\
\hline
\end{tabular}

$*, * *$ : Probability at $(p=0.05)$ and $(p=0.01)$ level of significance respectively in cassava which was already well established by Hahn et al. (1980); Lokko et al. (2004); Mohan et al. (2013).

CIM was performed and identified two QTLs in chrom7 and chrom22 (QTL1 and QTL2) respectively at a LOD score above 8.0. The QTL1 were flanked by NS97a and SSRY38a showed a PVE of $4 \%$ and a positive additive effect of 0.38 . The QTL2 identified by $\mathrm{CIM}$ was strongly associated with $\mathrm{CMD}$ resistance with an additive effect -0.76 and PVE of $17 \%$, (Table 5). The flanking markers viz., NS97c and SSRY30c associated with QTL2 were found to be significant by SMA. This suggested

\begin{tabular}{|c|c|c|c|c|c|}
\hline \multirow[t]{2}{*}{ QTL } & \multirow[t]{2}{*}{$\begin{array}{l}\text { Linkage } \\
\text { groups }\end{array}$} & \multirow{2}{*}{$\begin{array}{l}\text { Markers } \\
\text { associated } \\
\text { with QTL }\end{array}$} & \multicolumn{3}{|c|}{$\begin{array}{c}\text { Composite Interval } \\
\text { Mapping }\end{array}$} \\
\hline & & & $\begin{array}{l}\text { Peak } \\
\text { LOD }\end{array}$ & $\begin{array}{c}\text { Additive } \\
\text { effect }\end{array}$ & $\begin{array}{c}R^{2} \\
\text { value }\end{array}$ \\
\hline QTL1 & chrom7 & NS97 ${ }^{\mathrm{a}}-\mathrm{SSRY} 38^{\mathrm{a}}$ & 8.4 & 0.38 & 0.04 \\
\hline QTL2 & chrom 22 & NS97'-SSRY30 ${ }^{\circ}$ & 8.5 & -0.76 & 0.17 \\
\hline
\end{tabular}

that QTL present in Chrom7 was a minor gene and QTL on chrom 22 was a major gene. Phenotypic variance $<10 \%$ was considered as minor QTL and several such minor QTLs was reported to be associated with disease resistance (Li et al., 2001; Lindhout, 2002; Pilet-Nayel et al., 2002) which signified the present study. Also minor genes have small effects on the expression of phenotype for resistance showing quantitative segregation (Vidhyasekaran, 2008).

With multiple interval mapping, the main QTLs, its position and interactions of the QTLs were identified. Two main QTLs were identified in chrom 7 at a position of $0.1 \mathrm{cM}$ and $60.4 \mathrm{cM}$ position. The QTL located at $0.1 \mathrm{cM}$ position showed an additive effect of 1.1528 and dominant effect of -2.52 and was associated with marker NS97a. The second QTL located at a position of $60.4 \mathrm{cM}$ showed an additive effect of 0.3474 and dominant effect of -0.0325 and was associated with SSRY38a. There was prominent dominant by additive variance (DA) was identified with a value of 0.6962 (Table 6). The total $R^{2}$ value explained by this QTL interaction was found to be 0.95 (95\%) indicated a strong phenotypic effect. This is consistent with the studies of Wolfe et al. (2016), identified a major QTL on chromosome 8 and but on further dissection of major gene revealed the presence of two possible epistatic loci which accounted for the difference between moderate and strong disease resistance in germplasm.

In this study, heritability of the CMD resistance was also

\begin{tabular}{lccccccc}
\hline \multicolumn{7}{l}{ Table 6: QTL interactions found in chrom7 by MIM } \\
\hline \multirow{2}{*}{ Linkage groups } & Position & \multicolumn{5}{c}{ Multiple Interval Mapping } \\
\cline { 3 - 7 } & & Additive effect & Dominant effect & Additive variance & AD & DA & $\mathrm{R}^{2}$ value \\
\hline Chrom7 & $0.1 \mathrm{cM}$ & 1.1528 & -2.52 & 0.2491 & 0.6948 & 0.6962 & 0.95 \\
Chrom7 & $60.4 \mathrm{cM}$ & 0.347 & -0.0325 & 0.04231 & & & \\
\hline
\end{tabular}


analyzed. The total phenotypic variance and the genetic variance explained by CMD resistance trait were found to be 1.96 and 1.85 respectively. Using the phenotypic and genetic variance, the $\mathrm{H}^{2}$ of $\mathrm{CMD}$ resistance was calculated and was found to be $93 \%$. Using the additive variance (0.29141), the $\mathrm{h}^{2}$ of CMD resistance was calculated and was found to be $15 \%$. When compared the narrow sense heritability with broad sense heritability (93\%), the value obtained was very low $(15 \%)$ as it considered only additive variance which is the only transferrable variance from parents to progeny. Also the genetic gain from selection was found to be 0.4 . The main interactions identified in this study were AD and DA and was due to the heterozygous nature of the crop. Low narrow sense heritability and genetic gain in this study was explained by the epistatic interactions. This emphasis more of the interaction is genotype $x$ environment and additive in nature rather than that of single dominance. Some studies reported that epistatic interactions of QTLs limit their usefulness in MAS programmes (Tan et al., 2001). But Govindaraj et al. (2009) reported that the individual additive effects of these QTLs were sufficient enough to recruit them for MAS. Because of the interaction between different loci, the offspring phenotype will be largely influenced by the genetic background of the receptor line when marker-directed selection is carried out (Tan et al., 2001. The search for new resistance to CMD through RNA silencing was carried out by Vincent (2017). Differential responses of different genotypes to cassava geminiviral infection were studied by Paul et al. (2017). The identification of QTLs and the elucidation of their genetic control (main effects and their epistatic effects) are essential for the development of efficient MAS for improving breeding efficiency.

\section{Conclusion}

CMD resistance in cassava was contributed by both qualitative and quantitative disease resistance mechanism through SSR based genetic linkage map and QTL mapping. Heritability and expected gain from breeding were also calculated. This study reinforces the importance of epistasis in marker trait association studies, as the individual effect of a marker at locus depends on the marker genotype at other interacting loci.

\section{Acknowledgement}

The authors are grateful to the Director, Head, Division of Crop Improvement, ICAR-CTCRI, Thiruvananthapuram, for providing the laboratory facilities to do the work and University Grant Commission (UGC) for providing the financial support.

\section{References}

Abraham, A., 1956. Tapioca cultivation in India. Farm Bulletin. Indian Council of Agricultural Research, New Delhi, India. pp. 20.

Akano, O., Dixon, O., Mba, C., Barrera, E., Fregene, M., 2002. Genetic mapping of a dominant gene conferring resistance to cassava mosaic disease. Theoretical and Applied Genetics 105, 521-525.

Alagianagalingam, M.N., Ramakrishnan, K., 1966. Cassava mosaic in India. South Indian Horticulture 14, 441-448.

Allie, F., Pierce, E. J., Okoniewski, M.J., Rey, C., 2014. Transcriptional analysis of South African cassava mosaic virus infected susceptible and tolerant landraces of cassava highlights differences in resistance, basal defense and cell wall associated genes during infection. BMC Genomics 15, 1006. doi: 10.1186/1471-2164-151006

Altschul, S.F., Gish, W., Miller, W., Myers, E.W., Lipman, D.J., 1990. Basic local alignment search tool. Journal of Molecular Biology 215, 403-410.

Barrett, B.A., Griffiths,, M., Schreiber, N., Ellison, C., Mercer, J., Bouton, B., Ong, J., Forster, T., Sawbridge, G., Spangenburg, G., Bryan., Woodfield, D., 2004. A microsatellite map of white clover. Theoretical and Applied Genetics. 109, 596-608. doi:10.1007/s00122004-1658-0

Basten, C.J., Weir, B.S., Zeng, Z.B., 2003. QTL Cartographer: A reference manual and tutorial for QTL mapping, Department of Statistics, North Carolina State University, Raleigh, North Carolina.

Briddon, R.W., Markham, P.G., 1995. Family Geminiviridae. In: Virus Taxonomy. Sixth Report of the International Committee on Taxonomy of Viruses (Eds. Murphy FA, Fauquet CM, Bishop DHL, Ghabrial SA, Jarvis AW, Martelli GP, Mayo MA, Summers MD). Springer-Verlag, Vienna and New York, 158-165.

Ceballos, H., Iglesias, C.A., Perez, J.C., Dixon, A.G.O., 2004. Cassava breeding: opportunities and challenges. Plant Molecular Biology 56, 503-516.

Chaman, M.E., Copaja, S.V., Argandona, V.H., 2003. Relationships between salicylic acid content, phenylalanine ammonia lyase (PAL) activity, and resistance of barley to aphid infestation. Journal of Agricultural and Food Chemistry 51, 2227-2231. doi: 10.1021/jf020953b

Collard, B.C.Y., Jahufer, M.Z.Z., Brouwer, J.B., Pang, E.C.K., 2005. An introduction to markers, quantitative trait loci (QTL) mapping and marker assisted selection for crop improvement: The basic concepts. Euphytica 142, 169196. doi: 10.1007/s10681-005-1681-5

Czosnek, H., Eybishtz, A., Sade, D., Gorovits, R., Sobol, I., Bejarano, E., Rosas-Diaz, T., Lozano-Duran, R., 2013. Discovering Host Genes Involved in the Infection by the Tomato Yellow Leaf Curl Virus Complex and in the Establishment of Resistance to the Virus Using Tobacco Rattle Virus-based Post Transcriptional Gene Silencing. Viruses 5, 998-1022. doi: 10.3390/v5030998

Doyle, J.J., Doyle, J.L., 1990. Isolation of plant DNA from fresh tissue. Focus 12, 13-15.

FAOSTAT, 2017. Food and Agricultural Commodities 
Production.

Fargette, D., Fauquet, C., Grenier, E., Thresh, J.M., 1990. The spread of African cassava mosaic virus into and within cassava fields. Journal of Phytopathology 130(4), 289302. doi: 10.1111/j.1439-0434.1990.tb01179.x

Fargette, D., Fauquet, C., Thouvenel, J.C., 1988. Yield losses induced by African cassava mosaic virus in relation to the mode and the date of infection. Tropical Pest Management. 34, 89-91.

Fauquet, C., Fargette, D., 1990. African cassava mosaic virus: etiology, epidemiology and control, Plant Disease 74, 404-411.

Fauquet, C.M., Briddon, R.W., Brown, J.K., Moriones, E., Stanley, J., Zerbini, M., Zhou, X., 2008. Geminivirus strain demarcation and nomenclature. Archives of Virology 153(4), 783-821. doi: 10.1007/s00705-008-0037-6

Fregene, M., Angel, F., Gomez, R., Rodriguez, F., Chavarriaga, P., Roca, W.M., Tohme, J., Bonierbale, M.W., 1997. A molecular genetic map of cassava (Manihot esculenta Crantz), Theoretical and Applied Genetics 95, 431-441.

Gille, S., de Souza, A., Xiong, G., Benz, M., Cheng, K., Schultink, A., Reca, I. B., Pauly, M., 2011. O-acetylation of Arabidopsis hemicellulose xyloglucan requires AXY4 or AXY4L, proteins with a TBL and DUF231 domain. Plant Cell 23, 4041-4053. doi: 10.1105/tpc.111.091728.

Giovannoni, J.J., Wing, R.A., Ganal, M.W., Tanksley, S.D., 1991. Isolation of molecular markers from specific chromosomal intervals using DNA pools from existing mapping populations. Nucleic Acids Research 19(23), 6553-6558.

Goodstein, D.M., Shu, S., Howson, R., Neupane, R., Hayes, R.D., Fazo, J., Mitros, T., Dirks, W., Hellsten, U., Putnam, N., Rokhsar, D.S., 2012. Phytozome: A comparative platform for green plant genomics. Nucleic Acids Research. 40, D1178-D1186. doi: 10.1093/nar/gkr944.

Govindaraj, P., Vinod, K.K., Arumugachamy, S., Maheswaran, M., 2009. Analysing genetic control of cooked grain traits and gelatinization temperature in a double haploid population of rice by quantitative trait loci mapping. Euphytica 166(2), 165-176. doi: 10.1007/ s10681-008-9808-0

Hahn, S.K., Terry, E.R., Leuschner, K., 1980. Breeding Cassava for resistance to cassava mosaic disease, Euphytica., 29, 673-683. doi:10.1007/BF00023215

Hahn, S.K., Terry, E.R., Leuschner, K., 1980. Breeding Cassava for resistance to cassava mosaic disease. Euphytica 29(3), 673-683. doi:10.1007/BF00023215

Haitham, S., Kayyal, H., Ramsey, L., Ceccarelli, S., Baum, M., 2002. Segregation distortion in doubled haploid lines of barley (Hordeum vulgare L.) detected by simple sequence repeat (SSR) markers. Euphytica. 125, 265-272. doi:10.1023/A:1015861610226

Hanley, S., Barrer, J.H.A., Van Ooijen, J.W., Aldam, C., Harris, S.L., Ahman, I., Larsson, S., Kart, A.A., 2002. Genetic linkage map of willow (Salix viminalis) based on two Lycopersicon esculentum $\times$ L. pennellii $\mathrm{F}_{2}$ populations. Theoretical and Applied Genetics 99, 254-271.

Harrison, B.D., 1985. Advances in geminivirus research. Annual Review of Phytopathology 23, 55-82.

Jansen, R.C., 1993. Interval mapping of multiple quantitative trait loci. Genetics 135, 205-211.

Jansen, R.C., Stam, P., 1994. High resolution of quantitative traits into multiple loci via interval mapping. Genetics. 136, 1447-1455.

Jennings, D.L., 1976. Breeding for Resistance to African Cassava Mosaic Disese: Progress and Prospects. In: African cassava mosaic (Eds. Nestel BL). Report of an Interdisiplinary Workshop held at Muguga, Kenya.

Kao, C.H., Zeng, Z.B., Teasdale, R.D., 1999. Multiple interval mapping for quantitative trait loci. Genetics. 152, 1203-1216.

Kousik, C.S., Ritchie, D.E., 1999. Development of bacterial spot on near isogenic lines of bell pepper carrying gene pyramids composed of defeated major resistance genes. Phytopathology 89(11), 1066-1072. Doi: 10.1094/ PHYTO.1999.89.11.1066.

Legg, J.P., Fauquet, C.M., 2004. Cassava mosaic geminiviruses in Africa. Plant Molecular Biology 56, 585-599. doi:10.1007/s11103-004-1651-7

Li, Z., Jakkula, L., Hussey, R.S., Tamulonis, J.P., Boerme, H.R., 2001. SSR mapping and confirmation of the QTL from PI96354 conditioning soybean resistance to root knot nematode. Theoretical and Applied Genetics. 103, 1167-1173.

Liebhard, R.L., Gianfrancesschi, B., Koller, C.D., Ryder, R., Tarchini, E., Van de Weg., Gessler, C., 2002. Development and characterization of 140 new microsatellites in apple (Malus x domestica Borkh). Molecular Breeding 10, 217-241.

Lincoln, S., Dalyand, M., Lander, E., 1993. Constructing genetic Linkage maps with MAPMAKER/EXP Version 3.0: A Tutorial and Reference Manual. Whitehead Institute Technical Report. Whitehead Institute for Biomedical Research/MIT Center for Genome Research, Cambridge, MA.

Lindhout, P., 2002. The perspectives of polygenic resistance in breeding for durable resistance in breeding for durable resistance. Euphytica. 124, 217-226. Doi:10.1023/A:1015686601404

Lokko, Y., Gedil, M., Dixon, A.G.O., 2004. QTLs associated with resistance to the cassava mosaic disease: new directions for a diverse plant. In: Proceedings of the 4th International Crop Science Congress, $26^{\text {th }}$ September1stOctober, 2004, Brisbane, Australia.

Lu, H., Romero-Severson, J., Bernardo, R., 2002. Chromosomal regions associated with segregation distortion in maize. Theoretical and Applied Genetics. 105, 622-628. doi:10.1007/s00122-002-0970-9 
Mauch-Mani, B., Slusarenko, A.J., 1996. Production of salicylic acid precursors is a major function of phenylalanine ammonia-lyase in the resistance of Arabidopsis to Peronospora parasitica. Plant Cell. 8, 203-212.

McCouch, S.R., Doerge, R.W., 1995. QTL mapping in rice. Trends in Genetics 11(12), 482-487.

Michelmore, R.W., Paran, I., Kesseli, R.V., 1991. Identification of markers linked to disease-resistant genes by bulked segregant analysis: A rapid method to detect markers in specific genomic regions by using segregating populations. Proceedings of the National Academy of Sciences 88(21), 9828-9832.

Miedaner, T., Korzun, V., 2012. Marker-Assisted Selection for Disease Resistance in Wheat and Barley Breeding. Phytopathology Review. 102, 560-566. Doi: http:// dx.doi.org/10.1094/ PHYTO-05-11-0157

Mohan, C., Shanmugasundaram, P., Maheswaran, M., Senthil, N., Raghu, D., Unnikrishnan, M., 2013. Mapping new genetic markers associated with CMD resistance in cassava (Manihot esculenta Crantz) using simple sequence repeat markers. Journal of Agricultural Sciences 5, 57-65. Doi: http://dx.doi.org/10.5539/jas. v5n5p57

Mohan, C., Shanmugasundaram, P., Maheswaran, M., Senthil, N., Raghu, D., Unnikrishnan, M., 2013a. Mapping new genetic markers associated with CMD resistance in cassava (Manihot esculenta Crantz) using simple sequence repeat markers. Journal of Agricultural Science 5(5), 57-65. Doi: http://dx.doi.org/10.5539/jas.v5n5p57

Mohan, M., Nair, S., Bhagwat, A., Krishna, T.G., Yano, M., Bhatia, C.R., Sasaki, T., 1997. Genome mapping, molecular markers and marker assisted selection in crop plants. Molecular Breeding 3(2), 87-103. Doi: http:// dx.doi.org/10.1023/A:1009651919792

Nair, S.G., Unnirishnan, M., 2007. Recent trends in cassava breeding in India. In: Biotechnology and Ecology (Eds. Oritz R, Nassar NMA). Proceedings of the First International Meeting on cassava Breeding. University of Brazil, Brazil. pp. 37-53.

Navarro, L., Bari, R., Achard, P., Lison,, P., Nemri, A., Harberd, N.P., Jones, J.D.G., 2008. DELLAs control plant immune responses by modulating the balance and salicylic acid signaling. Current Biology 18, 650-655.

Nichols, R.F.W., 1947. Breeding cassava for virus resistance East Africa. Agricultural Journal 15, 154-160.

Nordborg, M., 2000. Linkage disequilibrium, gene trees and selfing: an ancestral recombination graph with partial self-fertilization. Genetics 154, 923-929.

Nugroho, L.H., Verberne, M.C., Verpoorte, R., 2002. Activities of enzymes involved in the phenylpropanoid pathway in constitutively salicylic acid-producing tobacco plants. Plant Physiology and Biochemistry. 40, 775-760. doi:10.1016/ S0981-9428(02)01437-7.

Okogbenin, E., Egesi, C.N., Olasanmi, B., Ogundapo, O., Kahya,
S., Hurtado, P., Marin, J., Akinbo, O., Mba, C., Gomez, H., de Vicente, C., Baiyeri, S., Uguru, M., Ewa, F., Fregene, M., 2012. Molecular marker analysis and validation of resistance to cassava mosaic disease in elite cassava genotypes in Nigeria. Crop Science. 52, 2576-2586. Doi:10.2135/cropsci2011.11.0586

Okogbenin, E., Egesi, C.N., Olasanmi, B., Ogundapo, O., Kahya, S., Hurtado, P., Marin, J., Akinbo, O., Mba, C., Gomez, H., de Vicente, C., Baiyeri, S., Uguru, M., Ewa, F., Fregene, M., 2012. Molecular marker analysis and validation of resistance to cassava mosaic disease in elite cassava genotypes in Nigeria. Crop Science 52, 2576-2586. doi:10.2135/cropsci2011.11.0586.

Okogbenin, E., Marin, J., Fregene, M., 2006. An SSR-based molecular genetic map of cassava. Euphytica 147, 433-440. Doi: 10.1007/s10681-005-9042-y.

Panaud, O., Chen, X., McCouch, S.R., 1996. Development of microsatellite markers and characterization of simple sequence length polymorphism (SSLP) in rice (Oryza sativa L). Molecular Genetics and Genomics. 252, 597-607. Doi:10.1007/BF02172406

Paterson, A.H., 1996. Making genetic maps. In: Genome Mapping in Plants (Eds. Paterson AH). RG Landes Company, Austin, Texas, USA, 23-39.

Paul, K., Muhammad, I., Elijah, A., Douglas, M., Justus, O., James, C.C., Nigel, J.T., 2017. Differential response of cassava genotypes to infection by cassavamosaic geminiviruses. Virus Research 227, 69-81.

Pilet-Nayel, M.L., Muehlbauer, F.J., McGee, R.J., Kraft, J.M., Baranger, A., Coyne, C.J., 2002. Quantitative trait loci for partial resistance to Aphanomyces root rot in pea. Theoretical and Applied Genetics. 106, 28-39. Doi: 10.1007/s00122-002-0985-2

Pinheiro, T.M., de Araujo, L.G., da Silva-Lobo, V.L., Prabhu, A.S., de Filippi, M.C., 2012. Tagging microsatellite marker to a blast resistance gene in the irrigated rice cultivar Cica-8. Crop Breeding and Applied Biotechnology 12, 164-170.

Quenouille, J., Paulhiac, E., Moury, B., Palloix, A., 2014. Quantitative trait loci from the host genetic background modulate the durability of a resistance gene: a rational basis for sustainable resistance breeding in plants. Heredity. 112, 579-587. Doi: 10.1038/ hdy.2013.138

Raghu, D., Senthil, N., Raveendran, M., Karthikayan, G., Pugalendhi, L., Nageswari, K., Mohan, C., 2012. Molecular Studies on the Transmission of Indian Cassava Mosaic Virus (ICMV) and Sri Lankan Cassava Mosaic Virus (SLCMV) in Cassava by Bemisia tabaci and Cloning of ICMV and SLCMV Replicase Gene from Cassava. Molecular Biotechnology 53, 150-158. Doi: 10.1007/ s12033-012-9503-1.

Ruiz, C., Asins, M.J., 2003. Comparison between Poncirus and Citrus genetic linkage maps. Theoretical and Applied 
Genetics. 106, 826-836.

Saunders, K., Salim, N., Mali, V.R., Malathi, V.G., Briddon, R., Markham, P.G., Stanley, J., 2002., Characterisation of Sri Lankan cassava mosaic virus and Indian cassava mosaic virus: evidence for acquisition of a DNA-B component by a monopartite begomovirus. Virology 293, 63-74. doi: 10.1006/viro.2001.1251

Sliwka, J., Wasilewicz-Flis, I., Jakuczun, H., Gebhardt, C., 2008. Tagging quantitative trait loci for dormancy, tuber shape, regularity of tuber shape, eye depth and fresh colour in diploid potato originated from six Solanum species. Plant Breeding. 127, 49-55.

Soosaar, J.L.M., Burch-Smith, T.M., Dinesh-Kumar, S.P., 2005. Mechanisms of plant resistance to viruses, Nature Reviews Microbiology. 3, 789-798. Doi: 10.1038/ nrmicro1239.

Spoel, S.H., Dong, X.H., 2012. Do plants achieve immunity? Defence without specialized immune cells. Immunology. 12, 89-100. doi: 10.1038/nri3141.

Sraphet, S., Boonchanawiwat, A., Tangphatsornroung, S., Boonseng, O., Tabata, S., Lightfoot, D.A., Triwitayakorn, K., 2011. Development of simple sequence repeat markers and construction of genetic linkage map of cassava (Manihot esculenta Crantz). Theoretical and Applied Genetics. 122, 1161-1170. Doi: 10.1007/s00122-0101520-1525

Sseruwagi, P., Sserubombwe, W.S., Legg, J.P., Ndunguru, J., Thresh, J.M., 2004. Methods of surveying the incidence and severity of cassava mosaic disease and whitefly vector populations on cassava in Africa. Virus Research 100(1), 129-142. Doi: 10.1016/j.virusres.2003.12.021

Tan, Y.F., Sun, M., Xing, Y.Z., Hua, J.P., Sun, X.L., Zhang, Q.F., Corke, H., 2001. Mapping quantitative trait loci for milling quality, protein content and color characteristics of rice using a recombinant inbred line population derived from an elite rice hybrid. Theoretical and Applied Genetics. 103, 1037-1045. Doi:10.1007/s001220100665

Tanksley, S.D., 1993. Mapping polygenes. Annual Review of Genetics 27, 205-233. Doi: 10: 1146/annurev. ge.27.120193.001225

Tanksley, S.D., Young, N.D., Paterson, A.H., Bonierbale, M.W., 1989. RFLP mapping in plant breeding: New tools for an old science. Nature Biotechnology 7, 257-264. doi:10.1038/nbt0389-257.

Thottappilly, G., Thresh, J.M., Calvert, L.A., Winter, S., 2004. Cassava. In: Loebenstein, G., Thottappilly, G., (Eds.), Virus and Virus-Like Diseases of Major Crops in Developing Countries. Dordrecht, The Netherlands, Kluwer, 107-65.

Toojinda, T., Broers, L.H., Chen, X.M., Hayes, P.M., Kleinhofs, A., Korte, J., Kudrna, D., Leung, H., Line, R.F., Powell, W., Ramsay, L., Vivar, H., Waugh, R., 2000. Mapping quantitative and qualitative disease resistance genes in a doubled haploid population of barley (Hordeum vulgare). Theoretical and Applied Genetics 101(4), 580-589.

Vidhyasekaran, P., 2008. Fungal pathogenesis in plants and crops. In: molecular biology and host defense mechanisms. CRC Press, Taylor \& Francis Group, Boca, Ratson, 509.

Vidya, P., Aswathy, G.H. Nair., Mohan, C., Ambu, Vijayan., Sreekumar, J., 2019. Studying the Disease Resistance and Morphological Variations in Cassava. International Journal of Bio-resource and Stress Management 10(4), 436-444. DOI: HTTPS://DOI.ORG/10.23910/ IJBSM/2019.10.4.2025

Vincent, N.F., 2017. The search for resistance to cassava mosaic geminiviruses: How much we have accomplished and what lies ahead Review. Front Plant Science. doi: 10.3389/fpls.2017.00408

Wolfe, M.D., Rabbi, I.Y., Egesi, C., Hamblin, M., Kawuki, R., Kulakow, P., Lozano, R., Carpio, D.P.D., Ramu, P., Jannink, J.L., 2016. Genome wide association and prediction reveals the genetic architecture of cassava mosaic disease resistance and prospects for rapid genetic improvement. Plant Genome. 9, 1-13. Doi: 10.3835/ plantgenome 2015.11.0118

Wu, K.K., Burnquist, W., Sorrells, M., Tew, T.L., Moore, P.H., Tanksley, S.D., 1992. The detection and estimation of linkage in polyploids using single dose restriction fragments. Theoretical and Applied Genetics. 83, 294-300. Doi: 10.1007/BF00224274

Yan, Z., Denneboom, C., Hattendorf, A., Dolstra, O., Debener, T., Stam, P., Visser, P.B., 2005. Construction of an integrated map of rose with AFLP, SSR, PK, RGA, RFLP, SCAR and morphological markers. Theoretical and Applied Genetics. 110, 766-777.

Yang, Y., Shah, J., Klessig, D.F., 1997. Signal perception and transduction in plant defense responses. Genes \& Development. 11, 1621-1639.

Young, N.D., 1996. QTL mapping and quantitative disease resistance in plants. Annual Reviews of Phytopathology. 34, 479-501. doi: 10.1146/annurev.phyto.34.1.479.

Zeng, Z.B., 1993. Theoretical basis of separation of multiple linked gene effects on mapping quantitative trait loci. Proceedings of the National Academy of Sciences. 90, 10972-10976.

Zeng, Z.B., 1994. Precision mapping of quantitative trait loci. Genetics. 136, 1457-1468.

Zhang, H., Gao, Z., Zheng, X., Zhang, Z., 2012. The role of G-proteins in plant immunity. Plant Signal Behaviour. 7, 1284-1288. doi: 10.4161/psb.21431. 